\title{
A Study on the Impacts of Dolphin Watching as a Tourism Activity: Western Mauritius as Case Study
}

\author{
Gowreesunkar Gaitree and Rycha Ian
}

\begin{abstract}
Dolphin-watching is now a major tourist attraction in many tropical islands. In the quest of capitalising on this opportunity, some destinations often overlook the impacts and implications of conducting such an activity. In the case of island destinations, it becomes more important to investigate this form of tourism attraction, given that islands face scarcity of resources and their self-sustaining growth are limited. With this as foundation, the present study investigates the impacts of dolphin watching as a tourism activity. Tamarin Bay (Mauritius) is chosen as case study. A mixed methodology approach is utilised. The findings show that dolphin-watching is conducted without control. The study proposes recommendations to island destinations' stakeholders engaging in this type of tourism activity.
\end{abstract}

Index Terms-Dolphin-watching, islands, impacts, implications.

\section{INTRODUCTION}

Dolphin watching is now a major tourist attraction in many tropical islands. While bigger nations like Australia, California, New Zealand, Scotland inter alia have been successful in developing dolphin watching as tourism activity, many small islands (for example Dominican Republic, Hawaii islands, Mediterranean islands, Mauritius inter alia) did not lag behind in capitalising on this form of tourism attraction. Likewise, the new and savvy tourists are also very much interested to go beyond the conventional sea, sun and sand tourism and indulge in more authentic forms of tourism. Researches reveal that dolphin watching, as an alternative form of tourism, is becoming a major tourist attraction in island destinations [1], [2]. But, in parallel, small islands are limited in size and resources according to studies conducted by [3]-[5], and in an attempt to diversify their existing tourism offer, dolphin watching is a preferred option for many (see for example [1], [6], [7]). In the quest of capitalising on this opportunity, many tourism destinations overlook the impacts and implications of dolphin watching on their destination, the dolphin and its people. This standpoint is also shared by Garrod \& Fennell (2004) [8] who observe that "dolphin watching has grown into a major tourist activity, and one that is evidently capable of delivering substantial socioeconomic benefits to many communities around the world in which it

Manuscript received April 7, 2014; revised September 19, 2014

Gaitree Gowreesunkar is with the Department of Tourism Leisure and Services at the University of Technology, Mauritius, La Tour Koenig, Pte aux Sables, Mauritius (e-mail: gvanessa@umail.utm.ac.mu).

Ian Rycha is with Tamarin Bay, Mauritius (e-mail: ian.rycha@hotmail.com). takes place, yet there are many concerns about its negative impacts". In the context of the island of Mauritius, a study conducted by the Mauritius Marine Conservation Society [9] revealed that many Mauritians earn their livelihood from marine life around the island and the monetary value generated just by the dolphin watching activity alone was estimated to Rs 150 million in 2009. This gives an indication on the potential of dolphin watching as an industry. Given that in Mauritius, there has been no recent research conducted in this line, it is plausible to suggest that dolphin watching as a tourism activity, represent an investigable area of study for the island. Dolphin watching takes place in deep sea and therefore involving in such type of marine activity not only impacts on the destination, but also on the dolphin, being the main component of the activity. Therefore, to engage in sustainable practice and to protect the destination and its tourism resources, it becomes important to gain an understanding on the impacts and implications, especially in the context of island tourism. In response, the present study seeks to address this knowledge gap and attempts to provide some practical information to a field which is gaining incremental importance in island tourism. The western coast of Mauritius is chosen as case study, given the centrality of its position for conducting this activity. The findings will thus shed light on the impacts of dolphin watching as a tourism activity and thereafter, practical implications will be discussed for Mauritius and for other island destinations offering dolphin watching as tourism product. The study brings a little contribution to small islands who are engaged in dolphin watching, as a tourism activity.

\section{LITERATURE REVIEW}

\section{A. Island Tourism and Dolphin Watching}

According to a study conducted by [10], islands, by their very nature, face a number of inherent disadvantages as they are small in size and they suffer from isolation, peripherality, external dependency and diseconomies of scale. As such, islands suffer scarcity of resources, meaning mainly that their alternatives for industrialisation and self-sustaining growth are limited [11]-[13]. Research on island tourism reveals that because of a lack of diversity in their resources, most island destinations overwhelmingly depend on their sea, sun and sand [11], [14]. As a result, island destinations often have similar and competing tourism products and with the limited choice, whenever they perceive a new way to diversify their tourism product, they do not hesitate to follow trends from more successful and established destinations. Dolphin watching has become a popular tourism activity, more than 
ever during the past 10 years [15], though as early as 1938, with the establishment of the first dolphinarium in Marineland (Florida), it was found to have tourism potential [16]. According to [17], dolphin watching is defined as tours by boat or air or from land, with some commercial aspect, to see or listen to any dolphin species. Dolphin watching is often seen as a lucrative form of tourism product whenever island destinations realise that they have the possibility of having dolphins in their water. New tourism products, afterall, open new opportunities for island development. Subsequently, island governments welcome dolphin watching, as a promising opportunity given that this helps in diversifying their tourism products and in offering a more authentic experience, thereby also reducing the prosperity gap between themselves and bigger tourism destinations (see for example, [1], [7]). When the other side of the coin is explored, it is found that, similar to other tourism activities, dolphin watching, may also face typical tourism drawbacks like multinational companies control, low level of local involvement among others.

\section{B. Stakeholders of the Dolphin Watching Industry}

The dolphin watching activity undoubtedly takes place with the help of stakeholders and stakeholders are those sea users who are directly or indirectly involved in the process; some are at sea with the aim to find dolphins (for examples, skippers and tourists) whereas others adventure themselves for other activities like fishermen or surfers but come across them while doing their activities. Table I details the main stakeholders of the dolphin watching industry:

TABLE I: MAIN DOLPHIN WATCHING STAKEHOLDERS

\begin{tabular}{|c|c|}
\hline \multicolumn{2}{|r|}{ Dolphin Watching Stakeholders } \\
\hline $\begin{array}{l}\text { Typology of } \\
\text { stakeholders }\end{array}$ & Examples \\
\hline $\begin{array}{l}\text { One-Person } \\
\text { Operations }\end{array}$ & $\begin{array}{l}\text { Marine naturalists or nature guides including sea } \\
\text { guides watching guides; sea kayak tour guides; } \\
\text { scuba diving instructors; charter fishing boat } \\
\text { operators; small and artisanal boat fishers; small } \\
\text { dolphin watching boat operations }\end{array}$ \\
\hline $\begin{array}{l}\text { Medium-Size } \\
\text { Operations }\end{array}$ & $\begin{array}{l}\text { Whale watching fleets, marine nature watching } \\
\text { companies, charter yacht companies }\end{array}$ \\
\hline $\begin{array}{l}\text { Large and } \\
\text { Multinational } \\
\text { Corporations }\end{array}$ & Cruise ship companies \\
\hline $\begin{array}{l}\text { Supporting } \\
\text { Businesses }\end{array}$ & $\begin{array}{l}\text { Coastal resorts; scuba tank fill shops, } \\
\text { windsurfing rental shops, charter air companies, } \\
\text { fishing equipment suppliers, island ferry } \\
\text { services, souvenir shops, boat maintenance } \\
\text { shops, artists and photographers }\end{array}$ \\
\hline $\begin{array}{l}\text { Government } \\
\text { Agencies }\end{array}$ & $\begin{array}{l}\text { Marine park management authorities, fisheries } \\
\text { control officers, tourism marketing and } \\
\text { promotion boards, law enforcement agencies, } \\
\text { marine safety organizations (coast guards, } \\
\text { navies, etc.) }\end{array}$ \\
\hline NGOs & $\begin{array}{l}\text { Clubs for scuba diving, surf lifesaving, yachting, } \\
\text { windsurfing, surfing, and fishing, birding } \\
\text { groups, whale and dolphin conservation groups, } \\
\text { other conservation groups involved in ecosystem } \\
\text { or wildlife protection }\end{array}$ \\
\hline Researchers & $\begin{array}{l}\text { Wildlife biologists, ecologists, oceanographers, } \\
\text { tourism researchers }\end{array}$ \\
\hline
\end{tabular}

Source: Adapted from Hoyt (2005) [18]

While previous studies (for example, [6], [15], [17]) have considered only people as stakeholders of the dolphin industry, the present study takes a somewhat different direction and argues that dolphins also are stakeholders. In fact, they are the most important stakeholders; without them, the activity cannot take place. There are various categories of dolphin involved in the dolphin watching activity. However, for the sake of this study, the Bottlenose dolphins are chosen as these are the species that mostly visit the Mauritian lagoon. The bottlenose dolphin is a widely distributed cetacean species with a range that includes both inshore and offshore waters [8]. According to the Mauritius Marine Conservation Society (MMCS), the bottlenose dolphins are vulnerable to many forms of human disturbance and this observation is an important premise to the current research. As a result, it becomes important to understand the impacts of conducting a tourism activity not only with them, but also on them.

\section{Impacts of Dolphin Watching as a Tourism Activity}

Ref. [19] defines impacts of tourism as changes which occur as a consequence of the industry. Research has undoubtedly revealed various advantages associated with dolphin watching as a tourism activity and these include among others, business opportunities, marine protection, improvement of locals' livelihood, economic prosperity (see for example, [1], [20], [21]. However, when the other side of the coin is explored, it is found that, similar to other tourism activities, dolphin watching, may also cause problems such as multinational companies control, low level of local involvement and leakage of foreign exchange earnings. For instance, a study conducted by [22] in the Hawaiian Islands showed that due to commercialisation of dolphin watching activity, various negative impacts were observed on the state's coastal and marine environments. However, due to this different form of tourism attraction which takes the dolphin as the core component, it is unlikely to determine all the possible impacts on those mammals. Still, there are empirical evidences that indicate that dolphins respond negatively to the presence of marine vessels, for instance, [18], [23]. To further support, a study conducted by Hawkins and Gartside (2009) [24] reveal that dolphins behave in the following way while interacting with vessels:

- Sustained approach: One or more dolphins approach a vessel within $10 \mathrm{~m}$ and remain close to the vessel with bodies orientated towards or parallel to the vessel and swimming at a slow speed;

- Bow-Riding: Dolphin is riding in the slip-stream or pressure wave at the bow of a travelling vessel;

- Wake-Riding: Dolphin rides at the stern of the vessel in the wave created by vessel's wake.

Likewise, in another study by [15], it was found that the presence of the tour boat affected the behavioural states (travelling, resting and feeding) of dolphins. More, they faced problems in terms of breathing rates; swimming directions, diving times, phonation rates [25]. Given that dolphins communicate by sound [24] and they are dependent on hearing to monitor and navigate in their environment [26], an uncontrolled marine environment with excessive activities disturbs their living. In fact, [23] observes that there are typically three levels of potential consequence of disturbances. Table II illustrates these: 
TABLE II: LEVELS OF DISTURBANCES

\begin{tabular}{|c|c|c|}
\hline \multirow[t]{2}{*}{ Immediate } & Direct & $\begin{array}{l}\text { Actions such as dolphin-vessel collisions } \\
\text { may change their behaviours or health }\end{array}$ \\
\hline & Indirect & $\begin{array}{l}\text { Death of a dolphin due to collision which } \\
\text { negatively impacts on breeding of the group }\end{array}$ \\
\hline \multirow[t]{2}{*}{ Short-term } & Direct & $\begin{array}{l}\text { Interfere behaviors such as pursuit/romance, } \\
\text { breeding, care of young and mother-calf } \\
\text { pairs which may cause energetic imbalances }\end{array}$ \\
\hline & Indirect & $\begin{array}{l}\text { May temporarily move use of range which } \\
\text { results into a permanent range reduction or } \\
\text { shift }\end{array}$ \\
\hline \multirow[t]{2}{*}{ Long-term } & Direct & Change in range size or distribution \\
\hline & Indirect & $\begin{array}{l}\text { Reduction of fitness through changes in } \\
\text { ecological/energetic systems, breeding } \\
\text { success and reproductive ability leading to a } \\
\text { decline in population }\end{array}$ \\
\hline
\end{tabular}

Source: Report on Responsible Whale \& Dolphin Watching (McCaffery \& Walker, 2012, [23])

While previous studies (for example [6], [15], [17]) have considered only people as stakeholders of the dolphin industry, the present study takes a somewhat different direction and argues that dolphins also are stakeholders. In fact, they are the most important stakeholders; without them, the activity cannot take place. There are various categories of dolphin involved in the dolphin watching activity. However, for the sake of this study, the Bottlenose dolphins are chosen as these are the species that mostly visit the Mauritian lagoon. The bottlenose dolphin is a widely distributed cetacean species with a range that includes both inshore and offshore waters [26]. According to the Mauritius Marine Conservation Society (MMCS), the bottlenose dolphins are vulnerable to many forms of human disturbance and this observation is an important premise to the current research. As a result, it becomes important to understand the impacts of conducting a tourism activity not only with them, but also on them.

\section{AREA OF STUDY}

Mauritius is a tropical island found in the Indian Ocean (Fig. 1) and the island is a popular sea, sun and sand destination. Among the 694,443 tourists who visited Mauritius from January to September 2013, there were many who were interested in marine activities including dolphin watching [27]. In fact, since the past ten years, dolphin watching has become a popular and lucrative tourist attraction as well as one of the key tourism activities in Mauritius. As a result, the Western Coast of Mauritius is now internationally known as a sanctuary for dolphins daily visited by those mammals which can be seen in the morning socializing and relaxing in the calm bays of Mauritius. The dolphins often choose Tamarin Bay as their natural habitat and this is the place where there is a concentration of boats since the dolphins are most of the time spotted at this place only. Given the potential of this particular form of tourism attraction, there has been a gradual increase in the number of boats coming from different places on the west coast namely from three main regions (Le Morne, Tamarin and Black River). Those boats come with visitors for the dolphin watching. In Mauritius, not many studies have been conducted in this line. To respond to this gap, and to get more information on the implications of dolphin watching, the Tamarin Bay is chosen as case study, given it is the preferred place for dolphins to rest, breed and socialize. Fig. 1 illustrates the area where the study was conducted.

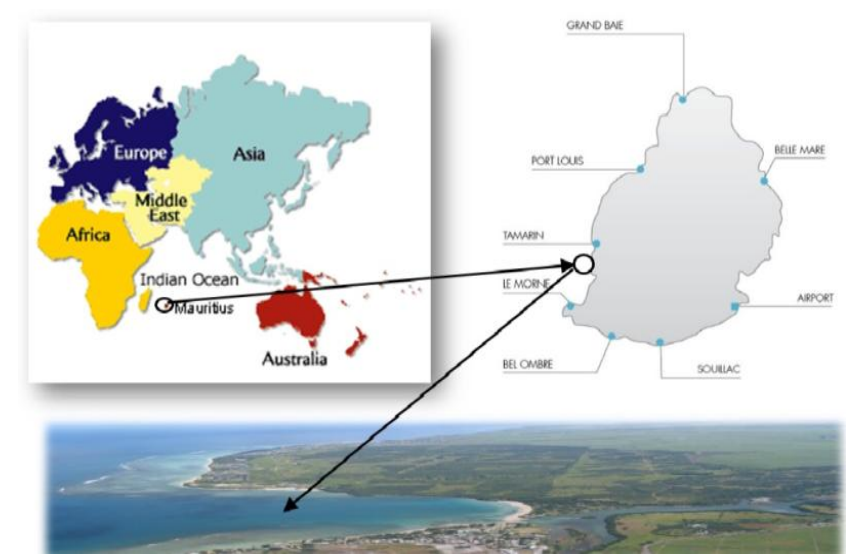

Fig. 1. Tamarin Bay of Mauritius (Source: Google Map 2013).

\section{Methodology}

The survey took place from February to September 2013. A mixed methodology approach was adopted. Primary data was obtained from semi structured questionnaires targeting tour operators and skippers. The list for skippers and tour operators were obtained from the Tourism Authority of Mauritius. According to the Tourism Authorities statistics, there are around 1500 skippers having their licenses to operate sea activities. However, the statistics specify that, of this population, only 60 of them operate as skippers for dolphin watching in the region of Tamarin and around 40 operators including tour operators, canvassers, agencies. Therefore, using the Raosoft sampling formula, the sample size of this study was calculated as 90 (53 skippers and 37 operators) for a population of 60 skippers and 40 operators. The simple random technique was utilised. In the case of the 60 skippers, 20 in each region (Le Morne, Black River and Tamarin) were selected at random. On the other hand, among the 40 operators scattered in the three regions, 20 operators were randomly chosen at Tamarin since it is the area of study and 10 from each of the two other. Study instruments comprised two types of questionnaires namely for tour operators and for skippers. Initially, it was decided to prepare a questionnaire for tourists in order to obtain information such as speed while watching dolphin, the number of boats and the distances between the vessels and the dolphins. However, after realising that this could affect their initial motive of dolphin watching and induce them in a different kind of observation, it was decided to undertake a non-participant observation at the area of study. Tour operators' questionnaires were sent by mail and phone calls were made to remind them of filling the questionnaires as well as discussing with them. Prior to the main survey, a pilot test was conducted on 10 skippers at Le Morne.

\section{FINDINGS, DISCUSSION AND RECOMMENDATION}

Various insightful findings emerged from the study, but the paper selects only few of them for discussion and makes some recommendations. On the positive side, findings show that dolphin watching at Tamarin Bay, contributed in economic prosperity of local entrepreneurs, improved sports and leisure 
for youth, boosted motivation for marine protection, employment opportunities, and conservation potential of endangered species among others. These observations reconciled with the outcome of previous studies as presented in the literature review section. On the negative side, various areas of concern were noted. At the onset, companies organized dolphin watching all year around without giving the marine environment a breathing space. Also, different types of vessels (speedboats) were utilised and these did not conform to prescribed norms.

Therefore, a lack of control was noted on behalf of relevant authorities. Existing laws were not enforced and they were too often, taken lightly by operators. Tamarin and Black River bays are resting, breeding and socializing areas for dolphins. In order to avoid disturbing the mammals during these activities, it is crucial to protect the very essence of this activity, which is the dolphin. As a result, the local regularities body can learn from other successful dolphin watching countries (Australia, California, Mediterranean islands). The Blueprint proposed by [18] is an important guideline to develop high quality, sustainable dolphin watching. Therefore the tourism authority with the help of the Mauritius Marine Conservation Society (MMCS), the Global Environment Facility (GEF) and the United Nations Development Programme (UNDP), may jointly develop appropriate codes of conduct adaptable for island tourism, rather that following standardised guidelines. To ensure that these are observed, the guidelines need to be enacted into law. For instance, existing guidelines are set to be followed, but the survey reveals that, on establishing guidelines, a choice is given to the operators and skippers to follow it or not. Therefore if these are legalised, there would be a better compliance to the prescribed code of conduct since stakeholders will have to abide by, irrespective of options or wants. Findings further unveil that the distance between the boat and the dolphins is not respected. For instance, skippers approach too closely to dolphins so that their clients have a wonderful view. This leads to conflicts between boats and skippers who compete to approach dolphins the nearest possible. In addition, some skippers and tourists tap in the water or whistle to attract dolphins but on doing so, the dolphins are disturbed and cannot communicate. The findings confirm the observations of [28]-[30] who also opine that in the presence of tour vessels, dolphin are affected and in the long run, they get intimidated and change their swimming directions. This implies that an island tapping fully on the potential of this tourism activity, might completely lose the dolphins. Other issues relate to the non-respect of guidelines while in the dolphin zone and the excessive speed when approaching dolphins. Too many boats not only harass the dolphins, but also detract tourists from their experience and instead of dolphin watching, it becomes boat watching. To address this, one large boat carrying many passengers would be less intrusive than many small boats with a few passengers each. The results indicate that there is not enough enforcement from tourism authorities on the regulations as well as code of ethics. Thus, island tourism relying on dolphin watching as a source of revenue, may face difficulty to substitute this type of tourism activities, especially is these have already been included in brochures, selling packages, tours, marketing campaigns among others. Sudden absence of dolphins might also have domino effects on all other stakeholders who are dependent on this activity for their businesses. In order to avoid disturbing the mammals during these activities, it is crucial to follow rules and regulations while watching dolphin. The tourism authorities with the help of a non-governmental organization namely Mauritius Marine Conservation Society (MMCS) and sponsor such as Global Environment Facility (GEF) and the United Nations Development Programme (UNDP), have altogether developed a set of codes of conduct and these need to be observed and monitored.

The findings show that code of conduct for the visit remains poorly regulated in many areas and suffers from a lack of internal direction. For example, not all tour companies conduct dolphin watching with a qualified guide; others prefer to rely on their tacit knowledge to guide their tour and in so doing, the main motive lies in cost cutting. This implies that dolphin watching activity does not really follow any code of conduct. This probably also explains the other negative impacts of the activity, for instance, the unacceptable behaviour of sea users like feeding or frightening the dolphins accompanied by water and noise pollution. Thus, skippers and tourists, who are not well informed on the species, adopt unfair practices as they ignore these impacts on the behaviour of dolphins which often result in minimization and sometimes elimination of the dolphin population, thus making this activity rarer or even extinct. Therefore, skippers should be provided with formal training before having permission to conduct this type of activity. In addition for a sustainable and responsible dolphin watching, there should be awareness programs for stakeholders and training to educate them about marine ecology, preservation and conservation of dolphins. To ensure sustainability of the tourism activity as well as the dolphins, local tourism authorities should exercise regular monitoring and control on the lagoon. The activity should be conducted at prescribed specific time so that dolphin have their own time and space to swim and reproduce without being disturbed by watchers. For instance, it would have been better if a national coast guard boat patrols around the day particularly during dolphin watching activity and if ever a skipper is caught doing unfair practices, the latter need to be warned and necessary actions should be taken immediately in front of the tourists. In this way, the skippers shall always keep in mind that they are under surveillance and that if ever they are caught, their skipper's or pleasure craft license could be withdrawn.

The Ministry of Tourism and Leisure might also oversee the activity by establishing a sea star system. This consists of star grading and gives accreditation to the boats operators which will range from 2-stars boats to 5-stars boats. Such accreditation should be based not only on aesthetic attributes of the boat but also on security measures for customers and compliance to guidelines. A brochure that explains 'blue' code of conduct during dolphin watching should be designed and distributed to tourists in order to advise them on safe and sustainable practices during the activity. The general population can be sensitized using media, posters and 
informative board at targeted public areas. In addition, a visitors' centre could be put in place at strategic points (e.g: Tamarin, Le Morne) for a briefing in the morning by an eco-guide. The local authority could introduce a blue fee to be paid each year which goes to a commission for the preservation and conservation of dolphins, for example the Mauritius Marine Conservation Society. To record the opinions of tourists without disturbing their trip, the design of a sustainability report card could be distributed to customers after their trip. This could help tourism authorities and other stakeholders have a daily and continuous report and records all over the year.

\section{CONCLUSION AND FUTURE RESEARCH}

This study has sought to give an insight on the impacts and implications of Dolphin watching as a tourism activity in the western coast of Mauritius. Taken together, this study has contributed to a broader and more comprehensive understanding of the impacts associated with dolphin watching in the tourism context. This piece of research makes a little contribution to the existing body of knowledge by offering an insight on theoretical and practical implications of dolphin watching in a small island like Mauritius. The contribution is extended to other island tourism destinations having similar resources and facing similar challenges as Mauritius. Although the study makes a useful contribution regarding the implications of dolphin watching in island tourism, the research is not free from limitations. One of the major weaknesses of the study was that it could not integrate a comprehensive list of skippers. The only list that was made available might not be representative of other skippers' opinions. Moreover, the list provided for skippers, canvassers and operators in the region was not complete, as the Tourism Authority was still in the process of updating its record. However, interview conducted with the director was useful since he informally gave information on the number of skippers in Mauritius. If a formal list was provided, then among the 1500 skippers in Mauritius, the exact number of skippers in the area of study would have been more transparent and hence stratified random sampling or cluster sampling could have been applied for a better representativeness of the population. In addition to the observation part, availability and hiring of boat during peak time for dolphin watching was a difficult and expensive phase. Another limitation related to travelling expenses. It was costly to travel to the area of study. Future researchers engaging in similar reviews might broaden the scope of their studies by investigating on a larger sample based on a comprehensive list. The feasibility of dolphin watching, as a tourism business as compared to other marine businesses might be studied to understand further implications and opportunity costs.

\section{ACKNOWLEDGMENT}

We would like to acknowledge the valuable support of the Mauritian Marine Society, residents of Tamarin and Dolphin-watching operators for their participation and co-operation.

\section{REFERENCES}

[1] C. Wiener, M. Needham, and P. Wilkinson, "Hawaii real life marine park: Interpretation and impacts of commercial marine tourism in Hawaiian Islands," Current Issues in Tourism, vol. 12, no. 5-6, pp. 489-504, 2009.

[2] C. C. Ling, "From catching to watching: Moving towards quality assurance of whale/dolphin watching tourism in Taiwan," Marine Policy, vol. 35, no. 1, pp. 10-17, 2011.

[3] K. Andriotis, "Tourism in Crete: A form of modernization," Current Issues in Tourism, vol. 6, no. 1, pp. 23-53, 2003.

[4] G. B. Gowreesunkar, C. P. Cooper, and R. Durbarry, "A study of the attitude and knowledge of residents, as tourism hosting community, in the region of Grand Bay (Mauritius)," in Proc. International Tourism and Sustainability Conference, Mauritius, September 2011, pp. 21-24.

[5] J. Steren. (June 2013). Tourism stakeholders perspective: The case of Palawan, Philippines. [Online]. Available: http://www. academia.edu

[6] R. Constantine, H. Dianne, D. Brunton, and T. Dennis, "Dolphin-watching tour boats change bottlenose dolphin (tursiops truncatus) behavior," Biological Conservation, vol. 117, pp. 299-307, 2013.

[7] E. C. M. Parsons and M. Draheim, "A reason not to support whaling A tourism impact case study from the Dominican Republic," Current Issues in Tourism, vol. 12, no. 4, pp. 397-403, 2009.

[8] B. Garrod and F. Fennell, "An analysis of whale watching codes of conduct," Annals of Tourism Research, vol. 31, no. 2, pp. 334-352, 2004.

[9] Mauritius Marine Conservation Society. (December 2012). [Online] Available: http://www.lemauricien.com

[10] K. Andriotis, "Problems of island tourism development: The Greek insular regions," in Coastal Mass Tourism: Diversification and Sustainable Development in Southern Europe, B. Bramwell, Ed. Clevedon: Channel View Publication, 2004, pp. 114-132.

[11] R. W. Butler, "Tourism development in small islands: Past influences and future directions," in Development Process in Small Islands States, D. Lockhart, D. Drakakis-Smith, and J. Schembri, Eds. London: Routledge, 1993, pp. 71-91.

[12] D. G. Pearce, Tourism Today: A Geographical Analysis, Longman New York, 1995.

[13] M. Cross and S. Nutley, "Insularity and accessibility: The small island communities of Western Ireland," Journal of Rural Studies, vol. 15, no. 3, pp. 317-330, 1999.

[14] D. Ioannides, "Planning for international tourism in less developed countries: Towards sustainability?" Journal of Planning Literature, vol. 9 , no. 3, pp. 235-59, 1995 .

[15] A. Arcangeli and A. Leviatano, "The short-term impact of dolphin-watching on the behaviour of bottlenose dolphins (tursiops truncatus) in western Australia," Journal of Marine Animals and Their Ecology, vol. 2, no. 1, pp. 1-7, 2009.

[16] A. Samuels and P. L. Tyack, "Flukeprints: A history of studying cetacean societies," in Cetacean Societies: Field Studies of Dolphins and Whale, J. Mann, R. C. Connor, P. L. Tyack, and H. Whitehead, Eds. 2000, pp. 9-45.

[17] E. Hoyt, Whale Watching 2001: Worldwide Tourism Numbers, Expenditures, and Expanding Socio Economic Benefits, Crowborough, UK: International Fund for Animal Welfare, 2005.

[18] E. Hoyt. (December 2013). Blueprint for dolphin and whale watching development. [Online]. Available: http:// www. hsi.org

[19] P. Simpson and G. Wall, "Environmental impact assessment for tourism," in Contemporary Issues in Tourism Development, D. Pearce and R. Butler, Eds. London: Routledge, 2000, pp. 232-256.

[20] K. R. Shapiro, "Whale watch passengers' preferences for tour attributes and marine management in Maui, Hawaii," Master's Thesis, Simon Fraser University, Burnaby, British Columbia, Canada, 2006.

[21] S. O'Connor, R. Campbell, H. Cortez, and T. Knowles, Whale Watching Worldwide: Tourism Numbers, Expenditures and Expanding Economic Benefits, Melbourne: Economist at Large \& IFAW, 2009.

[22] A. M. Friedlander, G. Aeby, E. Brown, A. Clark, S. Coles, and S. Dollar, "The state of coral reef ecosystems of the main Hawaiian islands," in The State of Coral Reef Ecosystems in the United States and Pacific Freely Associated States, J. Waddell, Ed. Center for Coastal Monitoring \& Assessment: Silver Spring, 2005, pp. 222-269.

[23] R. McCaffery and D. Walker. (December 2013). Report on responsible whale \& dolphin watching: The commercial advantages of a 
sustainable approach. [Online]. Available: http://www.thetravelfoundation.org.uk

[24] R. Hawkins and D. F. Gartside, "Interactive behaviours of bottlenose dolphins (tursiops aduncus)," During Encounters with Vessels, 2009.

[25] L. Bejder, A. Samuels, H. Whitehead, N. Gales, J. Mann, R. Connor, M. Heithaus, J. Watson-Capps, C. Flaherty, and M. Krützen, "Relative abundance of bottlenose dolphins (Tursiops sp.) exposed to long-term anthropogenic disturbance," Conservation Biology, vol. 20, pp. 1791-1798, 2006.

[26] N. Rako, I. Vilibic, and H. Mihanovic, "Mapping underwater sound noise and assessing its sources by using a self-organizing maps method," Journal of Acoustical Society of America, vol. 133, 2013.

[27] Statistics Mauritius. (December 2013). [Online]. Available: http://www.statsmauritius.gov.mu

[28] N. H. L. Barker and C. M. Roberts, "Scuba diver behavior and the management of diving impacts on coral reefs," Biological Conservation, vol. 120, no. 4, pp. 481-489, 2004.

[29] L. Goodwin and P. A. Cotton, "Effects of boat traffic on the behaviour of bottlenose dolphins," Aquatic Mammal, vol. 30, pp. 279-283, 2004.

[30] K. N. Holland and C. G. Meyer, Human Activities in Marine Protected Areas: Impacts on Substrates, Hawaii Institute of Marine Biology, 2003.

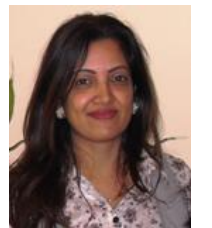

Gaitree Gowreesunkar has undertaken her $\mathrm{PhD}$ degree in tourism destination management and marketing, a merit scholarship based on her outstanding academic achievement. Her supervision team consisted of professor Chris Cooper in Oxford Brookes University and professor Durbarry in Bedfordshire University. She was awarded a second scholarship by the University Grants Commission, India to pursue her PhD-related researches at the University of Delhi.
She was a gold medalist for her first degree in tourism and hospitality management at the University of Technology Mauritius, where she was conferred a further award by the Mauritius Ministry of Tourism for her outstanding achievement in tourism. Presently.

Dr. Gaitree is a full time lecturer at the University of Technology (Mauritius) in the Department of Tourism, Leisure and Services (www.utm.ac.mu). Gaitree has participated in various tourism conferences. She is actually in the process of publishing more papers in the field of tourism. She is the chairperson of the research cell at ANPRAS (www.anpras.org) and is involved in various local tourism projects. Her research interest relates to island tourism, tourism management, tourism marketing and sustainable tourism.

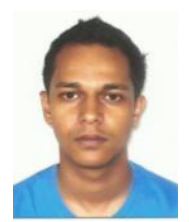

Ian Rycha is an independent researcher and is currently working as a tour operator. Ian is interested in marine researches and is presently studying tourism activities implications at Tamarin Bay. 